\title{
Proverbs: As the Manifestation of the Folksy Literature and Their Harmony with the Characters of Jamalzade's Stories
}

\author{
Zohre Mallaki $^{1}$, Raziye Rostami ${ }^{1} \&$ Fatemeh Noofeli ${ }^{1}$ \\ ${ }^{1}$ Literature Department, Faculty of Humanities, Boushehr, Iran \\ Correspondence: Zohre Mallaki, Literature Department, Faculty of Humanities, Boushehr, Iran. E-mail: \\ Z.Malaki@pgu.ac.ir
}

Received: July 23, 2017

Accepted: July 28, 2017

Online Published: September 17, 2017

doi:10.5539/res.v9n4p1

URL: http://doi.org/10.5539/res.v9n4p1

\begin{abstract}
This study is going to analyze the relationship and harmony between the proverbs used in Jamalzade's stories with the social situations of the characters. Jamalzade enjoyed this literature in order to get close to people's daily language and make his works more impressive. The research's data showed that Jamalzade could create a modern way of writing in Persian prose by using ordinary people's language and culture and combining it with Persian. He not only uses proverbs - as one of the most important factors of folksy literature in the formation of his stories, but also puts his best to use them properly according to the characters' social status; it has made his stories look more realistic. In fact, the relationship and appropriateness of the proverb and characters is such important for him that if he wants to use a proverb in several different situations, he make change in it.
\end{abstract}

Keywords: folksy literature, proverb, contemporary literature, Jamalzade's stories

\section{Introduction}

"When the author wants to approach to people's daily language he uses proverbs together with other functions of language, due to the closeness of proverbs and colloquial language" (Zolfaghari, 2010, p. 52) and "in many cases the author or poet uses proverbs in order to boost his argument power and increase his language's impression. In this way their diction looks deeper and more attractive. It will increase its effect on the reader. Proverbs with their historical background will make the text richer" (Shakoorzade Boluri, 2002, p. 8).

These have made Jamalzade pay a deep attention to proverbs in his simple language and use them together with people's specific expressions and allusions to make his works' atmosphere more Iranian. For 'proverbs' role in formal and verbal literature is important, because they are people's empirical wisdom and function as the mirror of their culture, opinions, lifestyle, conventions, behavior and other identical factors" (Zolfaghari, 2007, p. 28).

Mr. Jamalzade, our contemporary writer, believes that: "we should try hard in order to maintain and protect Persian language, words, expressions and proverbs; for all these are like precious treasures left for us and will disappear gradually and make Persian a poor language" (Jamalzade, 1999, pp. 193-292).

Generally, he believes that we should skillfully use proverbs in our stories; for it can be a great assist to maintain Persian proverbs, words and complete language, since novels and story books are the best source to keep language and its expressions. He says: "even in dictionaries you do not see this function, because in dictionaries you see a lot of functions described for a word, while it is vice versa in novels. Furthermore, there are lots of oral expressions and hints which cannot be found in dictionaries" (Jamalzade, 1999, p. 230).

Coordinating proverbs and characters' different types is among the writer's most important achievements; for people of different classes have different style of speaking and the use language exactly according to their social status, job, gender and age (Mirsadeghi, 2006, p. 464). This is approved by many researchers. "Social features can affect one's style of talking strongly. Academic language, language of the market, high language and the language of the people of the lower class are not the same ... expressing people's characteristics in dialogue depends on the type of the story, but anyway the story is we cannot dismiss these characteristics" (Yunesi, 1972, p. 330) and that a story character is "an element with moral and conscious features that exists in any story or drama: his behavioral and psychological qualities are revealed through what he or she does and says" (Sigar, 1972, p. 8). 
This is such an important issue the nowadays, critics and thinkers believe that as a character's psychological, mental and behavioral features must be harmonious to his class and status so must be his use of language, expressions and proverbs; that the reader would notice his class easily (Mavam, 1985, p. 11). Among Persian pioneer writers, although Dehkhoda's characters behave and speak according to their names and social status, Jamalzade must be considered as the first person who has used this technique together with proper proverbs consciously and established this harmony to his story's characters (Parsa et al., 2010, p. 28).

\subsection{Critical Background and Theoretical Foundations of Research}

According to the significance role of proverbs in Persian literature, many of researchers made remarkable efforts in order to collect them. It is necessary to name some of these researchers:

The first one is Ali Akbar Dehkhoda who has published Amsal va Hekam between 1929 and 1932. The book quickly attracts critics' opinions and becomes an encouraging support for others to collect proverbs.

Ahmad Akhgar in his collection collected more than five thousand Persian proverbs; firstly, he has written the proverbs and then in his couplets elaborated the meaning of each proverb (1940). Ebrahim Shakourzade has also collected many of Persian proverbs and discussed their meaning below them (1993). Mohammad Ali Haghighat Semnaani in addition to collecting them has discussed their relations to Persian poetry (1995). Mahmoud Ebadzade Kermani has separated poetry proverbs and elaborated on their historical bachground (1991).

These efforts were at first made only to collect proverbs, but researchers found out that they must study them in works of literature; that is why remarkable works were done, such as: Rahim Afifi, in his collection, tried to choose proverbs in the Persian poetry of $9^{\text {th }}$ century to $16^{\text {th }}$ century and express them in an alphabetical order (1992). Ali Reza Mansour Mo'ayed in his collection discussed proverbs in Shanname (1994); he also collected proverbs in Masnavi (1997). Mahmoud Mohammadi Borazjani collected provebs in Hafiz (1995).

There are also other works which have discussed proverbs more deeply. In fact, Hossein Zolfaghari in his article named "review on structure of proverb" was the first person to collect poetry proverbs (2007) and he expanded this topic later in another article called "the application of proverbs in Persian poetry" and discussed the topic independently (2012).

As it is clear, the named researchers firstly collected the proverbs and then elaborated on them; but no research has studied this topic yet; hence our aim is to study the role of proverbs in Jamalzade's stories and discuss their relations to the characters of the stories and to try to answer these questions: 1) How much attention does Jamalzade pay to proverbs and why? 2) For which class of society does Jamalzade use proverbs more? 3) Has Jamalzade established harmony between characters and proverbs in all situations? 4) Why has he made changes in the form of proverbs?

\subsection{Jamalzade}

Seyyed Mohammad Ali Jamalzade, contemporary writer, translator and researcher, was the first person who, due to his knowledge of Persian literature, along with European techniques of writing stories was aware of the importance of collecting and keeping the folksy language; he also reformed and reflected Persian proverbs and expressions in his stories and guided other researchers to enrich their language to reach the level of Dehkhoda (Dastgheyb, 1998, p. 246).

In fact, Jamalzade's love together with his artistic effort in order to revive Persian expressions and proverbs are obvious in his stories; in an age that only Arabic was considered as the foundation of literary insights. He believes that as we "try to stay healthy and keep our lives safe, we should try to maintain and protect our language and its expressions, words, verses and proverbs which are common among ordinary people's lives; otherwise all these will be disappeared by the passage of time and will cause language destitution" (Jamalzade, 2003, p. 17).

In his stories, he uses Persian language's worth naturally and by this he tries to make his stories' language closer to colloquial language. He wants to break the classic Persian euphuism and make it easier for ordinary people to understand, although he tries to keep it literary valuable. We see the examples of his desire to use Persian proverbs like: "yellow dog is jackal's brother", "the friendship of a bear" and "next time is beetroot's turn" in his story collection named Once Upon a Time. In fact, Jamalzade makes his stories "based on proverbs to make their educational aspects appear" (Mir Abedini, 1987, p. 155).

- Haven't you heard the story of the friendship of a bear? Kiss scorpion's sting and see how it rewards you (ibid., p. 81).

- $\quad$ Although they are not that far, since the yellow dog is jackal's brother (ibid., p. 115). 
"Jamalzade's use of proverbs has two main aspects; they make the text look more literary and rich as they prevent is from being too simple; especially when he uses them very musch (Mir Sadeghi, 2003, p. 597).

He sees the proper use of Persian proverbs as a beauty of language; for instance, when he talks about Hedayat Ali Khan, one of the main characters of the story "Asylum", he says: "I had never seen anybody like him in my life; a person who speaks Persian really beautifully and uses nice proverbs in his speech that never make you tired of listening to him" (Jamalzade, 1977, p. 120).

As it is common among modern Persian writers to use proverbs and expressions in their stories, it is not surprising to see him uses a series of proverbs next to each other (Dastgheyb, 1977, p. 28). For instance, in the following extract "he uses a group on proverbs with the same meaning, while it was enough to use only one of them and transfer the meaning; this sometimes makes him far from his goal of simplicity" (Mir Sadeghi, 2003, p. 598). For example:

\section{- Habit is truly like Samarra beggar and domestic cat and creditor Jew and Isfahani mucker; you send it out from the door and it returns from the window (Jamalzade, 2005, p. 101).}

Apart from his desire to use Persian expressions and proverbs he insists on using original topics; "problems and issues related to Iran, our fortunes and misfortunes, our past and future, whether it is ugly or pretty, good or bad" (Hamu, 1999, p. 84). He has pointed out several times that "I believe as our country is rich in subterraneous resources so is in topics and subjects for writing and among this old book of thousand leaves whose name is Iran, there are hundreds or thousands different original topics waiting for our talented hands to touch them and analyze them interestedly and present them to the market of literature" (ibid., p. 82).

\section{The Proportions of Proverbs with the Characters of the Stories}

Persian prose used to be really aristocratic that common people would not understand it; that is why it did not have the ability to progress and to reach new horizons, while "prose must be such that when readers read the story they should not feel the presence of something apart from the meaning; prose must not be tangible; it should affect but not be seen like air which is around us and our life depends on it, but we cannot see or touch it and its existence is felt just ehen it faces a problem (Rahgozar, 1990, p. 121).

Jamalzade, in fact, with strong historical, sociological and literary understanding could make out a universal face of a historical and educational prose. These stories can be considered as the first successful artistic effort of Persian prose in social context (Chlkowski, 1987, p. 204).

As Jamalzade becomes the pioneer and inviter of the modern Persian prose, he adds new type of importance to it. "Not only has he a valuable collection of Persian expressions and colloquial proverbs, but also uses them properly and artistically. And this is significant for a writer to choose well. He cares so much about using colloquial expressions and this attracts his main attraction" (Yusefi, 1988, Vol. 2, p. 265). In fact, the proverbs he narrates from his characters' points of view are appropriate for their situation; because as we stated earlier the writer should make harmony between language functions and story's characters and "loss of this and imposition of writer's will, ignoring the independence of each character and reducing the element of dialogue will manipulate the text" (Parsa \& Haji, 2013, p. 21). Observing this appropriateness and harmony is one of the ways a writer use to develop his story's characters and will let the reader understand characters' behavior and social status and with a little thinking he will realize characters' features (Mohammadi \& Talapour, 2012, p. 33); because "the most important element of realistic stories is characterization and a persuasive one is among the major goal of every realist writer" (Payande, 2010, p. 47). To make it clearer we will point out some examples:

\subsection{Illiterate Characters and Those of Lower Class of Society}

\subsubsection{Women}

In Jamalzade's stories the less focus is on women's characterization and they do not have a productive role in his stories; because the events of the story are reflections of the real society in which women have no role. Sexual view toward characters and as a result of that, descending women's roles is almost found in all communities and nations. We see that in Persian literature too. Studying colloquial culture and especially proverbs is the sign of injustice for women (Hosseinzade \& Basiri, 2009, p. 1). We should consider proverbs as the mirror of nations' culture; because with considering them we can understand women's roles in society better. In most of our proverbs women's personalities are described with negative qualities like ignorance, imperfection, weakness and misunderstanding. Persian culture and literature has a negative view toward women (Mousavi Dizkouhi, 2009). Jamalzade also has a similar view. In many scenes he describes women as people of lower class due to the people's view. He also uses related proverbs for them. For instance we will point out two women characters of 
his stories; one of them is caring and naïve, but the other one is a shrew and a woman of all sorts and as you see his used proverbs show the difference very well.

Shaah Baji Khanoom, who is an illiterate woman in "Asylum", uses related proverbs to his social class when she talks about Belgheys, who is Mahmoud's cousin.

"The best of all is that this patient, modest and gentle girl in its time becomes such an outspoken one that you cannot believe. She says her real words in josh and joke and that is when you believe that you should not judge a book by its cover" (Jamalzade, 1977, p. 56). And other examples are:

Red apple is good for disabled hands/the gem of the night closes the lamp to the dog's neck (ibid., p. 75)/say two, but listen to one (ibid., p. 60)/donkey will comeback as an ass (ibid., p. 70).

And now in the story named Shirazi Masoume, her landlord as she said was "a mean and hard-hearted woman, she was a woman of all sorts and could kill people for a little money" (Jamalzade, p. 29). When she wants to threaten Masoume she uses some related proverbs to her status:

"Then she came front and disordered my things and stuff and said you idiot have money to drink and get drunk, but you don't pay your fare? It is two months that you are playing with me. It seems that you don't know me yet. I have eaten thousand snakes to become a serpent" (ibid., p. 64).

\subsubsection{Men}

Most of Jamalzade's characters are men. Different characters with different features appear in stories and we see their different type of speech, for instance in "the Politician", the writer for Sheykh Jafar Panbezan who is from lower class and is not satisfied with his job and is always seeking a moment to find a better job uses related proverbs to his situation.

"I was almost in front of my store. My pocket was cleaner that brides' mirror. I had no money. The other shopkeepers said hello to me, but I knew what they meant. I knew that I couldn't buy on tick anymore. I knew that I should think of bread, because melon is just like water" (ibid., p. 56).

It is interesting to know that whenever Jamalzade wants to use a proverb which is not proper for a person of higher class he uses the expression "no offence" before it. For example when the narrator of "Ab Rah Name", who is an educated person, wants to say a proverb which is not proper for his personality uses the expression "no offence, but...".

"I said: Rouh Allah you haven't changed. No offence, but you are the same as you were. But for God's sake let me be today and forget about your old habits" (Jamalzade, 1960, p. 11).

\subsection{Educated People and People of Higher Class}

The language of Jamalzade's characters varies a lot. This variation is caused, because his stories are full of different characters with different situations: drome the lowest class of society to the highest. Each of these classes has its own language a language which is made by writer's confrontation with different people. One of these classes is the class of educated people and those of a higher class. Jamalzade uses proper proverbs for them.

For example, in "Politician" when they bring the message of Khaghan Alsaltane-a man of the higher class-, the proverbs used by him are exactly appropriate for him and different from others: "I was listening to your speech. It was obstreperous, but it was your decision anyway. Whatever the king does is sweet! It was professional of you. You are the Plato of your time. There will be your golden statue and in all academies your name will be remembered. I am sure with your grace, Khaghan Alsaltane will soon become a minister and we will feel at peace" (ibid., 2005, p. 65).

Another example would be Mahmoud, one of the "Asylum" characters, who uses such proverbs in his words:

"No offence, but I thought a pagan would think of others as pagans too. I fear you be unfair to these honorable people who do not care about earthly" (ibid., 1977, p. 23).

The narrator of the story "our tale is over" is also one of these high class and educated characters and in beginning of the story says: "I was crazy about writing down the proverbs and expressions and still I am. I was listening to him with my pencil in my hand and wrote down a lot" (Asylum, p. 56).

"God gifted him an expressive power of speech. And he cared about what the use of tongue in the mouth is" (ibid., p. 93). 
"He said when I was in Tehran I knew many people who were not poor but behaved as they were really poor. I told him: convenience and ease should be achieved with no suffering" (ibid., p. 29).

"I arranged his discorded hair and told him smilingly that there is no need to glance at me. It is me and I have come from a far place, the sun is like what it used to be" (ibid., p. 46).

"I sat next to him and kindly asked him to wake up. Jacob has come from Canaan. Tell me what a lament and mourning is that?" (ibid., p. 88).

\subsection{Experienced Characters}

Proverbs are like practical plans of people. They teach us "what to do when facing idiots, how to avoid evil deeds, how to achieve good deeds, when to be cautious, how to avoid traps, when to choose a reasonable method not feel regretful, what is the language of evil and what is the best way to bliss" (Shakoorzade, 2003, p. 7). There are experienced people in Jamalzade's stories whose words and use of proverbs shows their experience and knowledge.

For example, in the story "the Bear's friendship" Jafar Khan who "is mature and know things" (ibid., p. 71) uses appropriate proverbs in his speech. "Oh! Are you out of your mind? Do you want to get yourself killed? They are called bears and that is not reasonless. Haven't you heard the story of the friendship of a bear? Kiss scorpion's sting and see how it rewards you" (ibid., p. 81).

And in the story "scheming contract" when the landlord "whom people call Mr. know it all and is aware of everything" (Jamalzade, 2001, p. 76) wants to speak uses the following proverb. "Faride is like a Lor who is waiting for a colorful serpant to come out of the showman's bag. She is waiting to see what trick has her husband made on her" (ibid., p. 80).

\subsection{Religious and Clerical Characters}

Among the sources of proverbs all over the world are "religious and sacred texts, preachers, prophets, saints and mystics' words. The impression of religion on Persian proverbs, whether they before Islam or after it, is crystal clear. Quran and Hadith are the main sources. Extracting all Hadiths and verses is difficult" (Zolfaghari, 2007, p. 36).

Religious issues are tied to Iranians' lives and have huge reflections in their proverbs. Hadiths and Quran verses are directly or indirectly reflected in Persian proverbs. If we take a look at Jamalzade's stories, we see that he uses such proverbs only for religious characters; because he is aware of the lifestyle of different classes of people he creates in his stories very well; since "the story writer must have complete and exact information and practical experiences" (Zarinkoub, p. 211).

For example in the story "Persian is Sugar", Sheikh, who is really versed in law and religion, uses proverbs which are appropriate for his beliefs.

"The following words were presented well to audience due to the calmness of the speaker: 'Believers! Do not let your wrath controls your soul, because God says he likes those who control their wrath and forgive people" (Jamalzade, 2005, p. 33).

"May God bless you. Your point really inspires this that patience is the key of success" (ibid., p. 35).

As we saw, Jamalzade tried a lot to use proverbs according to the social status of his characters; because it will cause the story look more natural.

\section{Appropriateness of Proverbs and Stories' Contents}

One of the interesting facts is this that Jamalzade may use a proverb in different texts, but he makes a change in it to make it more proper for that subject; because "proverbs are a part of people's folklore culture and are seen in any language more or less. The formation of proverbs is not based on any scientific or reasonable principle" (Kalhor, 2001, p. 25). For instance, the proverb "bring a donkey and load beans" is among the common proverbs of people and Jamalzade uses it several times according to what its subjects take.

In the story "Persian is Sugar", when the narrator prevents Ramazan from crying and tells him that his cry would make him embarrassed among his friends he uses the proverb in this way:

“As Ranazan realized that I can speak Persian very well he started kissing my hands. He said: you are an angel. I stopped him and told him: I doubt about being a human, let alone the angel. A man must be brave. Why are you crying? Your partners will blame you and then bring a donkey and load embarrassment" (Once Upon a Time, Persian is Sugar, p. 42). 
Also in the story "Molla Ghorban Ali's Grievance", when Agha Sheikh fears that her wife realizes his love toward Haji Bazaz's daughter, he uses the proverb in his words in this way: "hearing the word spring, I remembered her long and beautiful hair and this time I remembered her innocent face which went red when saw an alien. And it made me feel sad. My heart started beating so hard that I thought its sound will wake my wife up and then bring a donkey and load shame" (Once Upon a Time, Molla Ghorban Ali's Grievance, p. 90). In the story "Gholtashan Divan", when the narrator speaks about people's problem about water division, which is their problem, he uses the word flock to magnify the meaning of shame".

"Evil and cruelty were shedding. Acquaintances were forgotten and unity was led to enmity. Every individual of the family were trying to take the last drops of the water to his or her pool and water storage. It was that time that you should bring flocks of donkeys and load shame" (ibid., 2000, p. 22).

\section{Conclusion}

Proverbs are a type of expression which are inspired by people's experiences in history and are signs of their dreams, sorrows, joys and hatreds and are reflections of every nation's intelligence and desire. As the proverbs are the links between the language of nobles and the commonality, when the writer wants to make his story's language closer to ordinary people's language uses proverbs and some other types of special expressions like allusions and sarcastic words. Jamalzade, the contemporary capable writer, tries to revive Persian proverbs and expressions in his stories; due to that he could help protect and maintain Persian and its expressions and common words and metaphors in an era when the laureates think of Arabic as the foundation of literary insight and knowledge; hence Jamalzade used proverbs, as an important part of folksy language, a lot in his stories. As Jamalzade believes that story's text should be so fluent that reader does not find any gap between it and the context, he uses proverbs completely relatedly to his prose to show the characters' personalities and social status.

\section{References}

Afifi, R. (2001). Proverbs in the Works of Poets of Third to Eleventh Hijry Centuries (3rd ed.). Tehran: Soroush.

Akhgar, A. (1940). Poetic proverbs, Kanoun Shoa'ra newspaper.

Alavi, F., \& Soheila, S. (2010). Studying Women's Roles in Realistic Works of Jamalzade and Balzac. Women in Culture and Art, 3, 39-58.

Aryanpor, Y. (1995). From Nima to our Time. Tehran: Zavar.

Balaei, C., \& Michelle, C. P. (1987). Persian Short Stories' Sources (K. H. Ahmad, Trans.). Tehran: Papirous.

Chlkowski, J. P. (1987). About Seyyed Mohammad Ali Jamalzade. In Mohammad Ali Jamalzade's memory by Ali Dehbashi (pp. 203-205). Tehran: Sasles.

Dastgheyb, A. A. (1977). Critics on Mohammad Ali Jamalzade's works. Tehran: Chapar.

Dastgheyb, A. A. (1987). Jamalzade's place in modern Persian prose. In Mohammad Ali Jamalzade's memory by Ali Dehbashi (pp. 245-255). Tehran: Sasles.

Dehkhoda, A. A. (1982). Amsal va Hakam. Tehran: Amir Kabir.

Ebadzade, K. M. (1991). Persian Poetic Proverbs and their Historical Roots. Tehran: Qesse Jahan Nama.

Haghighat, S., \& Mohammad, A. (1995). Persian poetic proverbs. Tehran: Gozare.

Hosseinzade, A., \& Mohammad, B. (2009). Studying gender in proverbs According to Hadiths and Verses. Women's Study Journal, 7(4), 7-31.

Jamalzade, M. A. (1960). Rah Ab Name. Tehran: Marefat.

Jamalzade, M. A. (1977). Asylum. Tehran: Marefat.

Jamalzade, M. A. (1997). Gholtashan Abad. Tehran: Sokhan.

Jamalzade, M. A. (1999). Story Writing. Tehran: Sokhan.

Jamalzade, M. A. (2001). The Old and the New. Tehran: Sokhan.

Jamalzade, M. A. (2003). Colloquial Dictionary. Tehran: Sokhan.

Jamalzade, M. A. (2005). Once Upon a Time. Tehran: Sokhan.

Kamshad, H. (2005). Founders of New Persian Prose. Tejran: Ney.

Mansour, M., \& Ali, R. (1994a). Proverbs in Masnavi. Tehran: Soroush.

Mansour, M., \& Ali, R. (1994b). Studying Proverbs is Shaname. Tehran: Soroush. 
Maugham, W. S. (1985). About Novel and Short Story (D. Kaveh, Trans.). Tehran: Sepehr.

Mir Abedini, H. (1987). Song of going back to the past. In Seyyed Mohammad Ali Jamalzade's Memory (pp. 151-164). Tehran: Sasles.

Mir Abedini, H. (1998). A Hundred Years of Story Writing. Tehran: Cheshme.

Mir Abedini, H. (2003). Fiction (story, short story, novel). Tehran: Mahour.

Mir Abedini, H. (2006). Story's elements. Tehran: Sokhan.

Mohammadi, B. M. (1995). Proverbs in Hafiz. Tehran: Mofid.

Mohammadi, E., \& Parisa, T. (2012). Characterization in Sooshoon. Textual Criticism Quarterly, 51.

Parsa, A. et al. (2010). The relationship between linguistic functions and characters in the story Persian is Sugar. Peyk Nour of Persian language and literature quarterly, 1(1), 37-50.

Payande, H. (2010). Short Story in Iran (Realistic and Naturalistic Stories). Tehran: Niloufar.

Rahgozar, R. (1990). Story writing's Alphabets. Tehran: Ministry of Culture and Islamic Guidance.

Segar, L. (2009). Characterization (M. Masoud, Trans.). Tehran: Rhrovan Pouyesh.

Shakourzade, E. (2001). Twelve Thousand Persian Proverbs. Mashhad: Astane Qods Razavi.

Yunesi, E. (1972). The Art of Story Writing. Tehran: Amir Kabir.

Yusefi, G. H. (1988). A Meeting with Authors (2nd ed.). Tehran: Elmi.

Zolfaghari, H. (2006). Persian Proverbs Bibliography. Iranian Studies Quarterly, 5(9), 53-77.

Zolfaghari, H. (2007). Iranian and religious identity in Persian proverbs. Iranian Studies quarterly, 8(2).

Zolfaghari, H. (2007). Studying proverbs structure: A discussion on sending proverbs and its differences with some similar types. Tarbiat Modarres Studies, 4(15), 31-62.

Zolfaghari, H. (2010). Aesthetics in Persian proverbs. Boustan Adab, 2(2), 51-82.

Zolfaghari, H. (2012). Proverbs use in Iranian poets' poetry. Gohar Gooya, 6(1), 95-122.

\section{Copyrights}

Copyright for this article is retained by the author(s), with first publication rights granted to the journal.

This is an open-access article distributed under the terms and conditions of the Creative Commons Attribution license (http://creativecommons.org/licenses/by/4.0/). 